\title{
КЛІНІЧНІ ЛЕКЦІЇ
}

УДК 616-022 : 616-053.31

\section{М.Л. Аряєв, Н.В. Котова}

Одеський національний медичний університет

(м.Одеса, Україна)
НЕОНАТАЛЬНИЙ (ДИСЕМІНОВАНИЙ) ЛICTEPIO3

Ключові слова: неонатальний лістеріоз.

\section{Епідеміологія}

Лістеріоз зустрічається у всіх країнах світу, при цьому клінічні прояви інфекції, викликаної лістеріями, зустрічаються досить рідко. Резервуаром інфекції у природі є багато видів гризунів, переважно мишоподібних, можуть бути птиці та риби. Основний шлях інфікування - при вживанні в їжу забруднених лістеріями продуктів (м'яса, не пастеризованого молока, овочів та фруктів). Менше значення має можливість інфікування при контакті $з$ хворими домашніми тваринами та птицею. За епідеміологічними даними, підвищення рівня захворюваності збільшується навесні. Можуть бути епідемічні спалахи серед вагітних, хворих на онкологічну патологію та спорадичні випадки $(0,34$ на 100 тис. населення у розвинутих країнах). Лістеріоз може виявлятися як вторинне захворювання у хворих 3 імунодефіцитними станами.

Безсимптомне носійство Listeria monocytogenes виявляється у $1 \%$ вагітних. Можлива передача збудника від матері до дитини. Гостра інфекція в першу половину вагітності призводить до тяжкого ураження плаценти, загибелі та викидання плода. Більш пізнє інфікування вагітної Listeria monocytogenes відбувається частіше і призводить до передчасних або термінових пологів 3 народженням дитини у тяжкому стані або з розвитком захворювання у перші дні або тижні життя.

Інфікування лістеріозом під час вагітності частіше відбувається при реінфекції або при реактивації латентної інфекції, чому сприяє гестаційне зниження імунітету.

Emionaтогенез. Збудником захворювання $\epsilon$ Listeria monocytogenes, що являє собою грампозитивний аеробний мікроорганізм розміром 0,5-0,6 мкм. Лістерії стійкі у зовнішньому середовищі, довгостроково зберігаються у випорожненнях, грунті, зерні, здатні розмножуватися при температурі $+4^{\circ}-+6^{\circ} \mathrm{C}$, однак,
Резюме. В лекиї наведено епідеміологію, етиопатогенез, клініку, діагностику, специфічне лікування та профілактику неонатального лістеріозу. швидко гинуть при нагріванні, під впливом дезинфікуючих засобів.

Вхідні ворота - слизові оболонки, пошкоджена шкіра, шлунково-кишковий тракт. У місці первинного проникнення збудника виникає запальна реакція, нерідко із залученням регіонарних лімфатичних вузлів. Через кров та лімфу лістерії проникають у ретикуло-ендотеліальну систему (печінка, селезінка, лімфатичні вузли), ЦНС, нирки, тощо, де відбувається їхнє розмноження з утворенням гранульом, які містять ретикулярні, моноцитарні клітини, клітинний детрит, змінені поліморфноядерні лейкоцити. У подальшому утворюються некротичні вогнища 3 можливим рубцюванням.

Клінічні прояви у матері під час вагітності. Як правило, Listeria monocytogenes у дорослих викликає захворювання, яке тяжко розпізнати клінічно та можна тільки діагностувати за допомогою чутливих серологічних методів. Гострі форми захворювання, що описуються у $65 \%$ матерів, які народили дітей 3 лістеріозом, характеризуються грипоподібними симптомами, раптовим початком, ознобом, підвищенням температури тіла, збільшенням лімфатичних вузлів, наявністю загальних ознак інфекційного токсикозу. Захворювання може проявлятися еритематозною чи крупноплямистою висипкою, що концентрується в області великих суглобів. Можлива поява на обличчі еритеми у формі метелика. У якості клінічних проявів лістеріозу на перший план можуть виступати ознаки ураження ЦНС (менінгоенцефаліт), гострого гастроентероколіту, пієлонефриту та ендокардиту.

У деяких жінок за декілька тижнів до пологів відзначалося підвищення температури тіла неясного генезу, м'язовий біль, дрижання, іноді тонзиліт або гнійний кон'юнктивіт.

Виникнення гострої інфекції в першу половину вагітності часто закінчується перери- 
ванням вагітності та гибеллю плода. Гостра інфекція у другій половині вагітності часто закінчується передчасними пологами, мертвонародженням, хоріоамніонітом.

Діагностика лістеріозу у матері грунтується на виділенні мікроорганізмів 3 крові, сечі, виділень шийки матки, а також із спинномозкової рідини. Зростання культур лістерій на простих середовищах стимулюється при додаванні в них крові, асцитичної рідини і глюкози. У мазках з 18-24-годинних колоній виявляється типове дифтероїдно - подібне розташування мікроорганізмів 3 невеликою кількістю S- або R-форм. 3 патологічного матеріалу лістерії виділяються легше, якщо тканини до внесення на поверхню живильного середовища протягом декількох тижнів зберігають при $4^{\circ} \mathrm{C}$.

Клінічні прояви лістеріозу в новонародженого. Неспецифічними наслідками лістеріозу у новонародженого і $€$ недоношеність, народження в асфіксії, синдром аспірації меконію. Лістеріоз у дитини може характеризуватися тяжким септикоподібним перебігом 3 перших діб життя. Вважається, що близько $20 \%$ випадків раннього сепсису в новонароджених обумовлені цим мікроорганізмом. При інфікуванні лістеріями у перинатальний період розвивається септичний грануломатоз з утворенням специфічних гранулем у різних органах.

Основні прояви неонатального лістеріозу: підвищення температури тіла, закладеність носу, ознаки дихальної недостатності. У ряді випадків можливий розвиток екзантеми. Висипка локалізується на шкірі спини, тулубу, кінцівок. Майже патогномонічною, але не постійною ознакою $є$ висипання на гіперемованій слизовій оболонці мигдаликів, ротоглотки та стравоходу гранульом сірувато-білуватого кольору розміром з просяне зерно. У більшості хворих спостерігають жовтяницю, збільшення печінки. Спленомегалія при лістеріозі буває рідше, ніж гепатомегалія. Меконій містить багато слизу, пофарбований у зеленуватий колір.

Неонатальний лістеріоз може проявлятися в перші 2-3 дні після народження дитини у вигляді вродженої пневмонії. Пневмонія при лістеріозі частіше носить інтерстиціальний характер, може ускладнитися розвитком гнійного плевриту. На рентгенограмі можна бачити множинні, густо розташовані, різко обмежені плями розміром не менше прося- ного зерна. Зміни в легенях нагадують бронхопневмонію або міліарний туберкульоз. Місцями зміни нагадують бджолині стільники. У периферичній крові виявляється лейкоцитоз та зсув лейкоцитарної формули вліво.

Іноді неонатальний лістеріоз проявляється як гнійний менінгіт з високою температурою тіла, опістотонусом або як енцефаліт без особливих змін у спинномозковій рідини. Частіше це проявляється на 2-4-му тижні життя.

Як виняток, неонатальний лістеріоз може нагадувати інфекційний мононуклеоз із моноцітозом у периферичній крові.

Діагностика має значні труднощі, грунтується на лабораторному виявлені збудника: у матері - в навколоплідних водах, у плаценті; у новонародженої дитини - 3 шлункового аспірату після народження, 3 крові, спинномозкової рідини та 3 рідини, отриманої при бронхо-альвеолярному лаважі. Серологічна діагностика недостатньо ефективна через хибно позитивні результати, обумовлені антигенним спорідненням лістерій та стафілококів.

Диференційна діагностика проводиться 3 раннім сепсисом, пневмонією, менінгоенцефалітом іншої етіології.

Лікування. Дітей з неонатальним лістеріозом необхідно ізолювати у зв'язку з ризиком передачі збудника іншим дітям.

Етіотропним лікуванням неонатального лістеріозу є антибактеріальна терапія з комбінованим застосуванням ампіциліну та гентаміцину. Тривалість лікування сягає 10-14 діб при пневмонії, 14-21 діб - при менігоенцефаліті.

Профілактика. Вагітним жінкам, що працюють у тваринництві, рекомендують тимчасово переходити на роботу, не зв'язану 3 тісним контактом із тваринами. У їжу рекомендують вживати тільки термічно оброблені м'ясні продукти, пастеризоване чи стерилізоване молоко.

Профілактика і заходи в епідемічному вогнищі - боротьба $з$ лістеріозом домашніх тварин. Ретельна термічна обробки м'яса i м'ясних продуктів, зЗаборона вживати не кип'ячене молоко. Вагітних, що працюють у тваринництві, необхідно тимчасово переводити на роботу, не зв'язану з постійним контактом із тваринами. Профілактика в оточенні хворого не проводиться.

Специфічна профілактика не розроблена. Для профілактики загибелі плода та розвитку неонатального лістеріозу велике значення 
має своєчасне виявлення інфекції у вагітних і проведення відповідної терапії.

Прогноз. При розвитку інфекції у матері під час вагітності ризик мертвонародження та пе- ринатальної смерті новонародженого дорівнює $22 \%$. Ризик летальності при маніфестації клінічних проявів неонатального лістеріозу дорівнює $50 \%$.

\section{Література}

1. Аряев Н.Л. Неонатология : учебник / Н.Л. Аряев. - Одесса: Одес. гос. мед. ун-т, 2006. - 836 с.

2. Шабалов Н.П. Неонатология : підручник / Н.П. Шабалов. - СПб., 2005. - Ч. І. - 512 с.; Ч. II. - 517 с.

3. Bacterial Infections and Pregnancy/ H.C. Yun, H. Hamza, L.B. Berkowitz [et al]/ - Medscape, $2011-$ Режим доступу: http://emedicine.medscape.com/article/235054-overview.

4. Centers for Disease Control and Prevention (CDC). Outbreak of listeriosis--northeastern United States, 2002. - MMWR Morb Mortal Wkly Rep. - 2002. - N 1(42). - P. 950-951.

5. Centers for Disease Control and Prevention Emerging Infections Program Foodborne Diseases Active Surveillance Network Working Group. Reduction in the incidence of invasive listeriosis in Foodborne Diseases Active Surveillance Network Sites, 1996-2003. / [ Voetsch A.C., Angulo F.J., Jones T.F., et al.]// Clin Infect Dis. - 2007. - N 44. - P. 513-520.

6. Congenital Infections, Part II: Parvovirus, Listeria, Tuberculosis, Syphilis, and Varicella / K, F. Satti, S. A. Ali, J.-H. Weitkamp// NeoReviews. - 2010. - N 11 (8). - P. e681 - e695.

7. Early onset of neonatal listeriosis. - Pediatr Int. 2011 Dec;53(6):1034-7. doi: 10.1111/j.1442200X.2011.03442.x.

\section{НЕОНАТАЛЬНЫЙ (ДИССЕМИНИРОВАННЫЙ) ЛИСТЕРИОЗ}

\author{
Н.Л. Аряев, Н.В.Котова
}

\section{Одесский национальний медицинский університет \\ (г. Одесса, Украина)}

Резюме. В лекции представлена эпидемиология, этиопатогенез, клиника, диагностика, специфическое лечение и профилактика неонатального листериоза.

Ключові слова: Неонатальный листериоз

\section{NEONATAL (DISSEMINATED) LISTERIOSIS}

\author{
M. L. Aryayev, N. V. Kotova
}

\section{Odessa National Medical University (Odessa, Ukraine)}

Summary. The epidemiology, etiology, pathogenesis, clinical manifestations, diagnosis, specific treatment and prophylaxis of neonatal listeriosis are presented in the lecture..

Keywords: neonatal listeriosis. 